UDC 336(025)

DOI: $10.24045 / p p .2017 .1 .9$

\title{
THE PROSPECTS OF IMPROVING THE FINANCIAL LITERACY OF THE POPULATION IN MODERN RUSSIA
}

\author{
T. A. Paladova \\ E. S. Maltseva
}

\author{
Candidate of Economic Sciences, associate professor \\ candidate of Economic Sciences, associate professor \\ Maikop State Technological University \\ Maykop, Republic of Adygea, Russia
}

\begin{abstract}
The necessity to improve the financial literacy of the population, in order to use resources as internal investment resources. The problems of inefficient use of personal savings and ways to solve them. The fullest possible use of the internal potential of savings of the population is one way of ensuring the stability of development of real economic sector in Russian Federation. One of the reasons of inefficient use of personal savings lies in the mistrust of the Russians is low financial literacy of the population, which does not allow to correlate the level of risk and the profitability of possible investments. The centers of financial literacy are aimed at solving the problem of low awareness of the Russians.
\end{abstract}

Keywords: finance; banks; financial literacy; population; savings; budget; investments; Russia.

Today there is a difficult economic situation in Russia, the country needs huge financial investment for the maintenance and development of the economy. The level of private and foreign investment, at the moment, is not enough, so it is necessary to create a model of management, in which the emphasis is on savings. Because of the unfavorable political situation and the imposition of economic sanctions in 20142015 investment attractiveness of Russia for foreign investors has significantly decreased and is not sufficient for the normal functioning of the economy.

The savings are part of household income after payment of taxes which is not spent on the purchase of consumer goods. Savings of the population determine the level of life and well-being in the country, the capacity of the domestic market, the size of the budget of the state and the dynamics of the investment process in the economy [5].

Financial literacy is a concept that goes beyond political, geographical and socioeconomic boundaries. The national and global economy depends on the contributions made into by individuals and groups, forming a complex network of interconnected and interdependent relationships.

There are many different ways to invest personal savings, each of which is designed for people with different income level and with different risk appetite. Unfortunately, to the majority of the Russians is available only a limited list of tools of investment of their own funds in the domestic economy, for example, deposits, deposits in mutual funds, pension contributions, the purchase of securities of developed or developing companies. At the same time the fullest possible use of the internal potential of savings of the population is one way of ensuring the stability of development of real economic sectors in our country. The growth rate of savings of the population, significantly outstripping the growth of income of the population, indicates the presence of potential resources that are not used today in the process of investing because of the immaturity of the mechanism of capitalization of savings.

Paradigmata poznóní. I . 20 I 7 
The reason of inefficient use of personal savings lies in the mistrust of the Russians to the activities of state and commercial structures, providing financial services. Perhaps this is due to the negative investment experience of previous years, when the financial pyramids replaced defaults, and vice versa, as well as low financial literacy of the population, which does not allow to correlate the level of risk and the profitability of possible investments. The government is intended to solve these problems by stabilization the banking system, improvement of legislation, that protects the interests of investors, and by increasing the level of financial literacy of the population.

If we consider the structure of monetary accumulation of the Russians for 2014-2015, it is characterized by the following trends: about $67 \%$ of savings are in the banking system, whether it is deposit accounts or money on credit cards, $14 \%$ are investments in securities, the percentage is low, since this type of deposit is characterized by a high degree of risk, and the remaining $19 \%$ of savings of the Russians are out of money turnover of the country - this is the main cause of inflation. Today, the deposits offer to cover the level of official inflation by an annual interest. Inflation is calculated on the basis of consumer price indices, published by the Federal State Statistics Service. It is impossible to make a profit on the deposit, but you can save the initial amount. The result of the influence of inflation on the information content of economic space is: undervaluation of property, organization expenses, cost of goods, works and services; overstatement of profits, profitability, tax payments; varied reinunerativeness of payment transactions [2].

Today, the majority of the Russians intend to produce and increase profits. People are studying methods to achieve this goal, but not all dare to make a contribution. The fact that part of the population does not understand what is happening with their deposits without the Bank doors. Since 2011, launched a joint project of the Central Bank and the Ministry of Finance of the Russian Federation "Improving financial literacy". The centers of financial literacy are aimed at solving the problem of low awareness of the Russians. This project, launched in a limited number of sites, aimed at creating a network of regional Centers of financial literacy [4]. The goal of this project is the assistance to citizens in overcoming the difficulties caused by the crisis, as well as to increase the level of competence of Russians in managing personal finances. Soon the idea was supported by the commercial organization and in 2014 the first in the south of Russia Financial Literacy Center at the bank "Center-Invest" was opened. The Center cooperates with the South Federal University, together they provide access to free financial advice. But the project, in the form, in which it is presented now, is not working at full capacity and requires adjustments. The solution to this problem can be:

- promotion of the project through the media, the Internet and advertising. More coverage of the activities of the Centers to attract the attention of the Russians;

- change the target audience. Today, the project is aimed at helping citizens in a down economy, but it is possible to cover a bigger segment, which is short of knowledge young people, for instance through cooperation with Universities.

As for global trends of improving financial literacy among young people, the hope for homeschooling financial instruments is not necessary - parents themselves are hardly versed in finance, but in many countries such a subject is introduced in the basic school program, but unified international standards are not developed. However, years of experience teaching the basics of financial literacy have a global non-profit organization "Junior 
Achievement", existing in Russia [1]. The Project on "Increasing budget literacy in Russia" is the next step taken by the Ministry of Finance in 2015. The project tasks include: the education of a new generation of citizens more actively involved in the processes of discussing and developing budget solutions and a deep understanding of the problems of the budgetary policy of the state that would contribute to the growth of civil responsibility of the population, trust to the government, participation in public control over the spending of budget funds [3]. This project is very important for Russia, its success would help to make budget policy and budget system understandable to the public. The project "Budget literacy" encourages the participation of young people - includes a project, oriented not only for students but also for high school students.

Raising the financial literacy of the population, but at a higher level, is engaged by the largest participants of the financial market of the country, such as investmentbrokerage company FINAM. The possible forms are the full-time and distance learning, participation in seminars, some of them are absolutely free. Also in some banks you can meet with your personal financial advisor who will offer each client the alternative deposits, taking into account the amount of his savings and the time frame in which he wants to make a profit.
Today the state is able to stabilize the economic situation in the country without the involvement of foreign investors and capital. This is possible through cooperation with the population: the raise of confidence to the banks, promotion of the economy, improving financial literacy will lead to the desired effect. In our opinion, the financial competence of the citizens is the key to formation of a strong civil society, raise in living standards, the formation of the middle class and the well-being of the country.

\section{Bibliography}

1. Financial Literacy [electronic resource]. // Public organization "Junior Achievement" URL: www.ja-russia.ru (reference date 10/18/2016)

2. Official statistics [electronic resource] // Federal State Statistics Service. URL: http://www.gks.ru/ (reference date 30/09/2016)

3. The project "Increasing budget literacy in Russia" [Electronic resource]. // Ministry of Finance of the Russian Federation. URL: http://www.minfin.ru/ru/press-center/ id_4 = 33253 \& area_id $=4$ \& page_id $=2119 \&$ popup $=\mathrm{Y}($ reference date $18 / 10 / 2016)$ ?

4. Promoting financial literacy of the population and the development of financial education in the Russian Federation [Electronic resource]. // Ministry of Finance. URL: http://www.minfin.ru/ru/om/fingram/ (reference date 10/01/2016)

5. Finance: Dictionary. 2nd ed. / B. Butler, B. Johnson, G. Siduel et al. Eds .: General Osadchaya IM M .: INFRA-M, 2000. - 496 p

(C) Paladova T. A., Maltseva E. S., 2017. 